\title{
RESEARCH ON DETERMINING AND REDUCING NOISE CAUSED BY MACHINERY USED FOR TRANSPORTING MINERALS IN THE OPEN PIT TYPE CAREERS
}

\author{
Andreea Cristina Tataru ${ }^{1}$, Dorin Tataru ${ }^{1}$, Aurora Stanci ${ }^{1}$ \\ ${ }^{1}$ University of Petrosani, Universitatii Street, no.20, Petrosani, \\ andreeastanci@yahoo.com, Roumania
}

\begin{abstract}
One of the most recent global environmental problem is noise pollution. Noise pollution is a component of environmental pollution. Like any other type of pollution, noise pollution has negative effects on environmental factors. The main sources of noise are: industry, urban areas and transport. To reduce the level of noise pollution is necessary to determine the pollution sources that cause the noise. In this paper we propose to determine the level of noise pollution produced by belt conveyor used to transport minerals in the open pit type careers. Also, we will present possible solutions to reduce the level of noise pollution produced by belt conveyors.
\end{abstract}

Keywords: noise pollution, open pit, transporting

\section{Introduction}

Noise pollution is an important environmental pollution by its harmful and its presence in all compartments of modern life. Noise pollution is a major problem for all economically developed or developing countries. Noise pollution is caused by various noises of machinery or industrial equipment, inside or outside of construction. (Dolores et al. 2014)

In Romania and in the world there is a growing trend in noise level. This trend is due to the economic development of sectors and transport. (Stepan et al., 2012)

\section{Theoretical considerations}

To avoid the harmful effects of noise on the human body and to ensure human normal life and work, European Union established noise limit levels that should not be exceeded. Fixing these values is complex and difficult because of the different ways of sound perception of people, of different action of the noise on the human body, of how noise affects human labor.

In the open pit exploitation, transport of minerals is performed using belt conveyors or heavy trucks. The main sources of noise pollution are the conveyor belts due to their location at very short distances from habited areas adjacent to the pits.

Maximum allowable noise level during the day, in industrial areas is $65 \mathrm{~dB}$, and the residential area is $55 \mathrm{~dB}$. (Mocuta, 2012)

Noise reduction in residential areas can be achieved by placing acoustic and soundproofing panels. Use of acoustic and soundproofing panels lead to additional costs of exploitation works. To reduce additional costs we should look for an optimal price-quality solution that satisfies the minimum requirements. 


\section{Results and discussions}

Due to the type of construction and operation of band conveyors, we have a source of structural noise - rolling noise. Rolling noise is the result of roughness or irregularities from the contact of the rolling surfaces. Spectral composition of rolling noise is broadband. Roller bearings used in the construction of band conveyors are the elements with periodic motion that make appear tonal components. In order to find solutions to combat noise pollution produced by the band conveyors we conducted noise monitoring for a period of 30 days. In order to monitor noise, we used digital measuring device 4 in 1 PVE-222. The digital measuring device 4 in 1 with multiple functions for the environment has been designed to combine the measurement of the sound level, light, humidity and temperature.

The background value of the noise level, measured near the belt conveyor in the immediate vicinity before starting it, is $48.1 \mathrm{~dB}$.

Table 1 The level of noise pollution produced by belt conveyor

\begin{tabular}{|l|l|l|l|}
\hline $\begin{array}{c}\text { Nr. } \\
\text { of } \\
\text { crt. }\end{array}$ & \multicolumn{1}{|c|}{ Measuring point } & \multicolumn{1}{|c|}{$\begin{array}{c}\text { Distance from } \\
\text { source } \\
(\mathrm{m})\end{array}$} & $\begin{array}{c}\text { The average value } \\
\text { measured of noise }(\mathrm{dB})\end{array}$ \\
\hline 1 & belt conveyor & 1 & 85,00 \\
\hline 2 & belt conveyor & 15 & 77,50 \\
\hline
\end{tabular}

From measured noise level in habited area near to careers, it was found exceed of the noise level by $20 \mathrm{~dB}$. To achieve the reduction of the noise pollution we propose to use acoustic and soundproofing curved screens. (Stanci and Stanci 2014)

For the production of the curved screens can be used soundproofing and acoustic boards, steel, aluminum and mineral fibers, or you can use polycarbonate panels. Air stratification between the edges hardness polycarbonate plates ensures proper insolation. Depending on the type of the polycarbonate used, different values are obtained for noise attenuation, the values are shown in Table 2.

To select the ideal economically and noise attenuation level below we present a comparative study of the costs of achieving a sound attenuation and soundproofing panel with a length of $5 \mathrm{~m}$ - this is the distance between two pillars supporting belt conveyor. For isolation of belt conveyors, we propose method 1 or 2 of soundproofing panels. Curved screens for both methods are shown in figures 1 and 2 .

Curved screen for the method 1 has a length of $5 \mathrm{~m}$ and a height of $1.6 \mathrm{~m}$. This curved screen is not having any supporting structure, being caught directly on the metallic structure of the belt conveyor (figure. 1).

Table 2 Noise attenuation level of polycarbonate panels

\begin{tabular}{|l|c|l|c|}
\hline $\begin{array}{c}\text { Plate size depth } \\
(\mathrm{mm})\end{array}$ & $\begin{array}{c}\text { Isolation index * } \\
(\mathrm{dB})\end{array}$ & $\begin{array}{c}\text { Plate size depth } \\
(\mathrm{mm})\end{array}$ & $\begin{array}{c}\text { Isolation index * } \\
(\mathrm{dB})\end{array}$ \\
\hline $4 \mathrm{~mm}$ Twinwall & 6 & $20 \mathrm{~mm}$ Triplewall & 22 \\
\hline $6 \mathrm{~mm}$ Twinwall & 8 & $20 \mathrm{~mm}$ Fourwall & 22 \\
\hline $8 \mathrm{~mm}$ Twinwall & 13 & $25 \mathrm{~mm}$ Fivewall & 23 \\
\hline $10 \mathrm{~mm}$ Twinwall & 20 & $30 \mathrm{~mm}$ Twinwall & 25 \\
\hline $10 \mathrm{~mm}$ Fourwall & 20 & $32 \mathrm{~mm} \mathrm{XX-wall}$ & 25 \\
\hline $\begin{array}{l}16 \mathrm{~mm} \\
\text { Triplewalla }\end{array}$ & 21 & $32 \mathrm{~mm}$ Sevenwall & 25 \\
\hline $16 \mathrm{~mm}$ Fivewall & 21 & $35 \mathrm{~mm}$ XX-wall & 25 \\
\hline $16 \mathrm{~mm}$ M wall & 21 & $35 \mathrm{~mm}$ Sevenwall & 25 \\
\hline
\end{tabular}




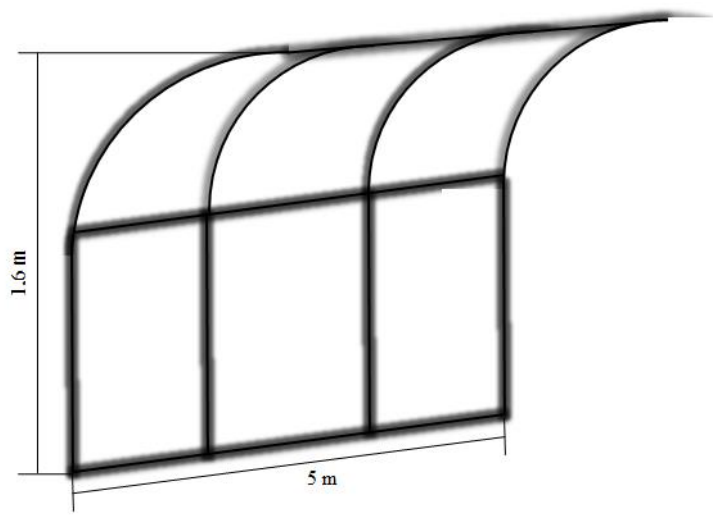

Figure. 1 Soundproofing curved panel screen for the 1st method

The curved screen for the method 2 has a length of $5 \mathrm{~m}$ and a height of $2.1 \mathrm{~m}$. At the base of curved screen is provided with a supporting structure directly on the ground (Figure. 2).

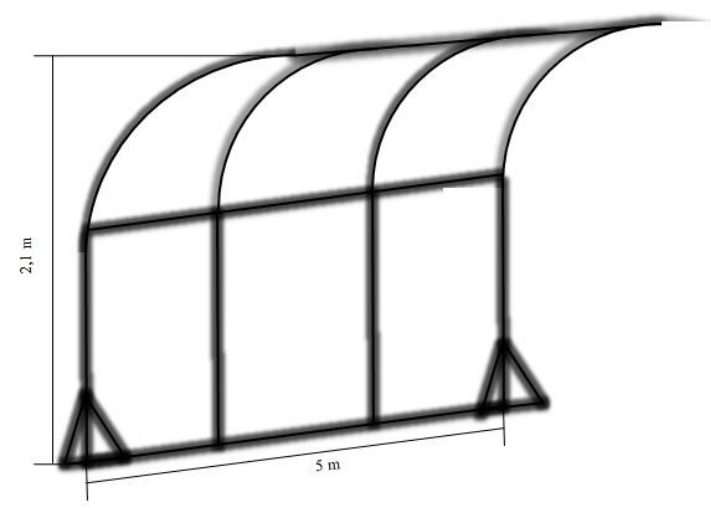

Figure. 2 Model of curved screen method 2

For the panels made 2 of steel, aluminum and mineral fibers, economic calculation is presented in Tables 3 and 4

Table 3 Economic calculation to produce the curved panel screen from steel, aluminum and mineral fibers for the first method

\begin{tabular}{|c|l|c|c|c|c|}
\hline $\begin{array}{c}\text { Nr. } \\
\text { of } \\
\text { Crt }\end{array}$ & \multicolumn{1}{|c|}{ Material } & UM & Quantity & $\begin{array}{c}\text { Price/unit } \\
\text { RON }\end{array}$ & $\begin{array}{c}\text { Total } \\
\text { price } \\
\text { RON }\end{array}$ \\
\hline 1 & Material-panel & $\mathrm{m}^{2}$ & 15,5 & 306,9 & $5.370,75$ \\
\hline 2 & Pillar HEA160 & buc & 3 & 842,58 & $2.527,74$ \\
\hline 3 & Base panel & $\mathrm{m}$ & 5 & 334.8 & 1.674 \\
\hline 4 & Clamping screws & buc & 6 & 2,12 & 12,72 \\
\hline 5 & $\begin{array}{l}\text { Locking nut for the clamping } \\
\text { screws }\end{array}$ & buc & 6 & 6,99 & 41,94 \\
\hline & TOTAL & - & - & - & $9.627,15$ \\
\hline
\end{tabular}


Table 4 Economic calculation to produce the curved panel screen from steel, aluminum and mineral fibers for the second method

\begin{tabular}{|c|l|c|c|c|c|}
\hline $\begin{array}{c}\mathrm{Nr} \\
\mathrm{Crt}\end{array}$ & \multicolumn{1}{|c|}{ Material } & UM & Quantity & $\begin{array}{c}\text { Price/unit } \\
\text { RON }\end{array}$ & $\begin{array}{c}\text { Total price } \\
\text { RON }\end{array}$ \\
\hline 1 & Material-panel & $\mathrm{m}^{2}$ & 15,5 & 306,9 & $5.370,75$ \\
\hline 2 & Pillar HEA160 & buc & 3 & 842,58 & $2.527,74$ \\
\hline & TOTAL & - & - & - & $7.898,49$ \\
\hline
\end{tabular}

Economic calculation for the realization of the curved panel screen from polycarbonate for the first method is shown in Table 5, and for the second method is shown in Table 6. For curved panels we use $16 \mathrm{~mm}$ Polycarbonate boards.

Table 5 Economic calculation to produce the curved panel screen for the first method

\begin{tabular}{|c|l|c|c|c|c|}
\hline $\begin{array}{c}\text { Nr. } \\
\text { of } \\
\text { Crt }\end{array}$ & Materials & UM & Quantity & $\begin{array}{c}\text { Price/unit } \\
\text { RON }\end{array}$ & $\begin{array}{c}\text { Total } \\
\text { Price, } \\
\text { RON }\end{array}$ \\
\hline 1 & $\begin{array}{l}16 \mathrm{~mm} \text { Polycarbonate Twinwall } \\
\text { panel }\end{array}$ & unit & 1 & 500,85 & 500,85 \\
\hline 2 & Flat bar & $\mathrm{m}$ & 16,4 & 6,32 & 103,65 \\
\hline 3 & Angle steel & $\mathrm{m}$ & 3,2 & 16,88 & 54,02 \\
\hline 4 & Metal screw & unit & 62 & 1,10 & 68,20 \\
\hline 5 & Secured locking nut & unit & 62 & 5,49 & 340,38 \\
\hline 6 & Rubber Washers & unit & 62 & 0,39 & 23,87 \\
\hline 7 & Cheder & m & 1,6 & 1,02 & 1,63 \\
\hline 8 & Fasting screws & buc & 6 & 2,12 & 12,72 \\
\hline 9 & $\begin{array}{l}\text { Secured locking nut for the } \\
\text { fasting screws }\end{array}$ & unit & 6 & 6,99 & 41,94 \\
\hline & TOTAL & - & - & - & $1.147,26$ \\
\hline
\end{tabular}

By using steel panels, aluminum and mineral fibers we can achieve noise attenuation up to $40 \mathrm{~dB}$ according to technical sheet, and for a $16 \mathrm{~mm}$ polycarbonate plate has a noise attenuation up to $21 \mathrm{~dB}$ as shown in Table 1.

Table 6 Economic calculation to produce the curved panel screen for the second method

\begin{tabular}{|c|l|c|c|c|c|}
\hline $\begin{array}{c}\text { Nr. } \\
\text { of } \\
\text { Crt }\end{array}$ & Materials & UM & Quantity & $\begin{array}{c}\text { Price/unit } \\
\text { RON }\end{array}$ & $\begin{array}{c}\text { Total } \\
\text { Price, } \\
\text { RON }\end{array}$ \\
\hline 1 & $\begin{array}{l}\text { 16 mm Polycarbonate Twinwall } \\
\text { panel }\end{array}$ & unit & 1 & 500,85 & 500,85 \\
\hline 2 & Flat bar & $m$ & 14,2 & 6,32 & 89,74 \\
\hline 3 & Angle steel & $m$ & 9,2 & 16,88 & 155,30 \\
\hline 4 & Metal screw & unit & 72 & 1,10 & 79,20 \\
\hline 5 & Secured locking nut & unit & 72 & 5,49 & 395,28 \\
\hline 6 & Rubber Washers & unit & 72 & 0,39 & 27,72 \\
\hline 7 & $\begin{array}{l}\text { Support pillars from profile } \\
\text { UMP }\end{array}$ & $\mathrm{m}$ & 3,6 & 28,50 & 102,60 \\
\hline 8 & Cheder & $\mathrm{m}$ & 2,1 & 1,02 & 2,14 \\
\hline & TOTAL & - & - & - & $1.352,83$ \\
\hline
\end{tabular}


Using soundproofing panels not only has effect on reducing the level of noise pollution but also reduce the degree of air pollution and dust entrained by airflow produced by bands on transportations.

To establish the level of sound attenuation of belt conveyor used in the open pit, where realized measurements at different distances from belt conveyors with and without curved polycarbonate screen $16 \mathrm{~mm}$. The results obtained from the measurements are shown in Table 7.

Table 7 The level of sound attenuation by using curved screens of $16 \mathrm{~mm}$ polycarbonate plate

\begin{tabular}{|c|l|c|c|c|c|}
\hline $\begin{array}{c}\text { No. } \\
\text { crt. }\end{array}$ & $\begin{array}{c}\text { Measuring } \\
\text { point }\end{array}$ & $\begin{array}{c}\text { Distance } \\
\text { from } \\
\text { source } \\
{[\mathrm{m}]}\end{array}$ & $\begin{array}{c}\text { Measured } \\
\text { value of } \\
\text { noise } \\
{[\mathrm{dB}]}\end{array}$ & $\begin{array}{c}\text { Measured } \\
\text { value of } \\
\text { noise } \\
{[\mathrm{dB}]}\end{array}$ & $\begin{array}{c}\text { Attenuation } \\
\text { using } \\
\text { polycarbonate } \\
\text { panels } \\
{[\mathrm{dB}]}\end{array}$ \\
\hline 1 & $\begin{array}{l}\text { Belt } \\
\text { conveyors }\end{array}$ & 1 & 85 & 67 & 18 \\
\hline 2 & $\begin{array}{l}\text { Belt } \\
\text { conveyors }\end{array}$ & 5 & 84.5 & 66 & 18,5 \\
\hline 3 & $\begin{array}{l}\text { Belt } \\
\text { conveyors }\end{array}$ & 10 & 81,5 & 62 & 19,5 \\
\hline 4 & $\begin{array}{l}\text { Belt } \\
\text { conveyors }\end{array}$ & 15 & 77.5 & 57 & 20,5 \\
\hline 5 & $\begin{array}{l}\text { Belt } \\
\text { conveyors }\end{array}$ & 20 & 75 & 53 & 22 \\
\hline 6 & $\begin{array}{l}\text { Belt } \\
\text { conveyors }\end{array}$ & 25 & 72.5 & 48,5 & 24 \\
\hline
\end{tabular}

From Table 7 it can be seen that the attenuation caused by the use of curved polycarbonate plate screen of $16 \mathrm{~mm}$ is sufficient to reduce noise levels below the maximum allowed for living quarters.

\section{Conclusions}

Polycarbonate panel's costs are much lower than those for steel panels, aluminum and mineral fibers.

In case of band conveyors noise isolation produced by polycarbonate plates is enough during the day, thus reducing the noise level below the maximum allowable and simultaneously reduce the degree of air pollution and dust entrained by airflow from band conveyors in the vicinity of habited areas.

Acoustic and soundproofing curved panel screens from polycarbonate offer entire satisfaction of criteria relating to the noise isolation and the price.

Curved panel screens made of steel, aluminum and mineral fibers produce higher noise attenuation, but production prices are very high compared to other polycarbonate panel screens. 


\section{References}

Baican G., Boldor C., lanc I. (2001), „Reabilitarea Haldelor de Steril Rezultate în Urma Extragerii Lignitului în Carierele din Bazinul Minier al Olteniei“, Al IV-lea Congres Mondial de Mediu Minier 25-30 iunie Băile Felix.

Dolores M., Morales H., Quesada-Rubio J.-M.*, Navarrete-Álvarez E., Rosales-Moreno M.-J., Del-Moral-ÁvilaM.-J. (2014), Geostatistical analysis of the causes of environmental noise in Spain, Environmental Engineering and Management Journal Vol.13, No. 10, 2507-2515 http://omicron.ch.tuiasi.ro/EEMJ/.

Mocuta G. (2012), Noise Pollution Emitted as a Consequence of the Urban Transport Development, Journal of Environmental Protection and Ecology, 13 (2A), 852.

Stanci A. C., Stanc A. (2014), Methods to Reduce the Noise Pollution Produced by Band Conveyors, Journal of Environmental Protection and Ecology, 15 (1), 242.

Stepan D., Ionel I., Stefanescu W., Dungan L. I. (2012), Noise Control in Railway Vehicles, Journal of Environmental Protection and Ecology 13 (2), 561. 